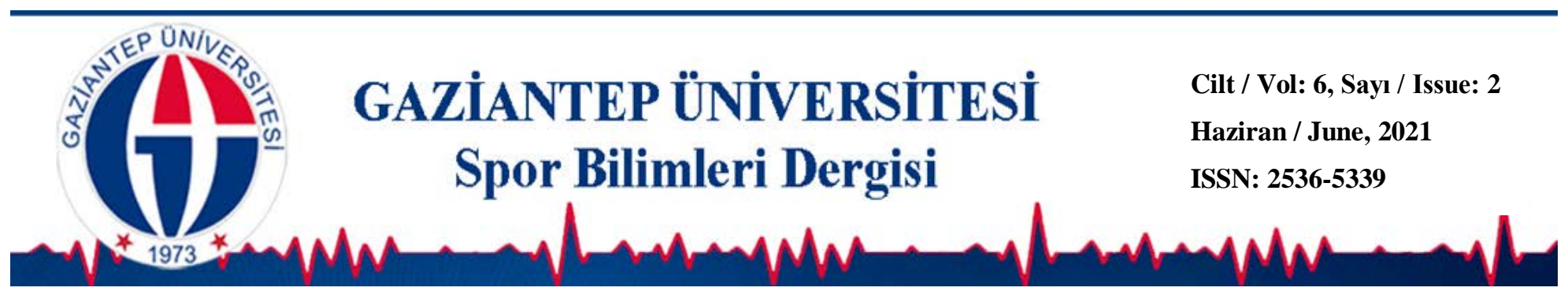

\title{
Covid-19 Pandemi Sürecinde Gençlik ve Spor İı Müdürlükleri Çalışanlarının İş Motivasyonları ve Kaygı Düzeylerinin İncelenmesi
}

\author{
Çilem BULUT ${ }^{* *}$ (D) \\ Savaş DUMAN ${ }^{1}$ \\ ${ }^{1}$ Aydın Adnan Menderes Üniversitesi, Spor Bilimleri Fakültesi, AYDIN
}

do) DOI: 10.31680/gaunjss.914850

Orijinal Makale / Original Article

Geliş Tarihi / Received: 12.04 .2021
Kabul Tarihi / Accepted: 07.06.2021

\section{Öz}

Covid-19 Pandemi sürecinde Manisa, İzmir ve Aydın; Gençlik ve Spor İ Müdürlüklerinde çalışan bireylerin İş motivasyonu ve kaygı düzeylerinin incelenmesi amacıyla yapılan bu araştırmada, iş motivasyonu ölçeği ve durumluk-sürekli kaygı ölçeği kullanılmıştır. Manisa İzmir ve Aydın Gençlik ve Spor İı Müdürlüğünde çalışan 324'ü erkek 186'sı kadın olmak üzere toplam 510 gönüllü katılımcıya çevrimiçi ortamda ulaşılmıştır. Araştırmadan elde edilen verilerin analizinde SPSS 26.0 paket programı kullanılmıştır. Analiz seçiminde, verilerin normal dağılım gösterip göstermediği, normal dağılım varsayımları, çarpıklık-basıklık değerleri ile Box Plot ve Histogram grafikleri incelenerek belirlenmiştir. Elde edilen bulgular incelendiğinde; Durumluk kaygı ile "içsel motivasyon-dış düzenleme" arasında anlamlı ilişki tespit edilememiştir. Durumluk kaygı iş motivasyonunun diğer alt boyutları arasında negatif ve zayıf düzeyde anlamlı ilişki tespit edilmiştir. Sürekli kaygı ile "içsel motivasyon-dış düzenleme", "sosyal statü ve özgüvene dayalı içsel motivasyon" arasında anlamlı ilişki tespit edilememiştir. Sürekli kaygı ve iş motivasyonunun diğer alt boyutları arasında negatif ve zayıf düzeyde anlamlı ilişki tespit edilmiştir. Aydın ili Gençlik ve Spor î̀ Müdürlüğü çalışanlarının iş motivasyonu düzeylerinin Manisa ve İzmir ilinde bulunan Gençlik ve Spor İI Müdürlüğüne oranla daha yüksek olduğu sonucuna ulaşıImıştır.

Anahtar Kelimeler: Kaygı, Motivasyon, İş Motivasyonu, İçsel ve Dışsal Motivasyon.

\section{Investigation of Job Motivation and Anxiety Levels of Youth and Sports \\ Provincial Directors 'Employees During the Covid-19 Pandemia Process}

\begin{abstract}
Manisa, İzmir and Aydın during the Covid-19 Pandemic process; Work motivation scale and state-trait anxiety scale were used in this study, which was conducted to examine the work motivation and anxiety levels of individuals working in Provincial Directorates of Youth and Sports. A total of 510 volunteer participants, 324 men and 186 women, working in Manisa İzmir and Aydın Provincial Directorate of Youth and Sports, were reached online. SPSS 26.0 package program was used in the analysis of the data obtained from the research. In the analysis selection, it was determined whether the data showed a normal distribution, normal distribution assumptions, skewness- kurtosis values, and Box Plot and Histogram graphs. When the findings are examined; No significant relationship was found between state anxiety and "internal motivation-external regulation". A negative and weakly significant relationship was found between state anxiety and other sub-dimensions of work motivation. No significant relationship was found between trait anxiety and "intrinsic motivation-external regulation", "intrinsic motivation based on social status and self-confidence". A negative and weakly significant relationship was found between trait anxiety and other sub-dimensions of work motivation. It has been concluded that the work motivation levels of the employees of Aydın Province Youth and Sports Provincial Directorate are higher than that of the Youth and Sports Provincial Directorate in Manisa and İzmir.
\end{abstract}

Keywords: Anxiety, Motivation, Job Motivation, Internal And External Motivation

\footnotetext{
* Sorumlu Yazar: Çilem BULUT
}

e-mail: bulutcilem0@gmail.com 

195.

\section{Giriş}

Kaygı, yaşamın bir parçası olmakla beraber insanı olumsuz etkileyen unsurlardan birisidir. Tükel ve Alkın (2006)'a göre kişiye dönük tehlike ve risklere karşı onu harekete geçmeye hazırlayan biyolojik uyarıya anksiyete (kaygı) adı verilmektedir.

Kaygıyı; durumluk kaygı, sürekli kaygı, normal kaygı, ekzojen (dış) ve endojen (iç) kaygı olmak üzere dört başlık altında inceleyebiliriz. Bireyin tehlike anında sezdiği kaygı durumluk kaygıdır. Anlık ve gelip geçici kaygı olarak düşünülebilir. Durumluk kaygı hissedilen sorun ya da problemin şiddetli olduğu anlarda ortaya çıkarak bireyi olumsuz yönde etkilemektedir. Sürekli kaygı ise kişinin çevreye bağımlı olmadan, endişeli, karamsar, huzursuz, aşırı heyecanlı ve yüksek düzeyde duyarlı olması ve bu şekilde tepkilerde bulunması olarak tanımlanmaktadır (Erözkan, 2020). Sürekli kaygı düzeyinin bireyde meydana getirebileceği durumluk kaygının etki gücünü ve süresini belirleyebilmektedir (Öner ve Len Compte, 1998; Alisinanoğlu ve Ulutaş, 2000).

Karagüven (1999)'e göre kaygıya sebep olan nedenler bireyden bireye farklılıklar göstermektedir. Kişilerde kaygıya sebep olan nedenlerden bazıları iş ortamından kaynaklanırken bazıları da kişisel faktörlerden meydana gelebilmektedir. Kaygı bireyin performansına etkileri olan önemli bir değişkendir (Akarçeşme, 2004; Ciucurel, 2012; Cerit, Gümüşdağ, Evli, Şahin ve Bastik, 2013) ve bireyin performansını olumsuz yönde etkileyen kaygının çalışma hayatında iş motivasyonunu da etkileyeceği düşünülmektedir. Kişisel motivasyonu ve iş motivasyonunu etkileyen farklı unsurların olduğu yadsınamayacak bir gerçeklik iken, bu araştırmada daha çok kaygı ve iş motivasyonu arasındaki ilişki irdelenmeye ve bir sonuca ulaştırılmaya çalışılmıştır.

Latince karşılığı "movore" ve "motum" köklerinden türetilen motivasyon kavramı Türkçede harekete geçirme anlamına gelmektedir (Harmancı, 2008). Noermijiati (2015)'e göre motivasyon, bireyde bir şeyler yapmak için ortaya çıkan itici güçtür; insanın hedeflerine ulaşmak için sarf ettiği güç, yön ve kalıcılığı tanımlayan bir süreçtir. Robbins (1993)'e göre iş motivasyonu, bazı bireysel gereksinimlerin tatmin edilebilmesi için örgütsel amaçlara yönelik olarak üst düzeyde çaba sarf etme, isteklilik ve koşullandırma olarak tanımlanabilir. İşletmelerde veya belirli bir örgütte çalışanların iş motivasyonlarının artırılmasının amacı; çalışanların iş performansını yükseltmek ve çalışanlarda daha fazla çalışma isteği oluşturabilecek faktörleri 
bulmak, bunları karşılamaya çalışmaktır (Özmutaf ve Aktekin, 2016). Bir başka deyişle, kişilerin performansını yükseltme yoluyla iş verimliliğini artırmak ve kurumsal hedeflere ulaşmayı basitleştirmektir (Dalkıran, 2018).

İş motivasyonunun; "örgütsel hedefler", "bireysel intiyaçlar" ve "çaba" olmak üzere üç temel bileşeni vardır (Önen ve Kanayran, 2015). Bunlar göz önüne alınarak kurum yöneticilerinin, kurumsal hedeflere ulaşabilmek için çalışanların kişisel gereksinimlerini dikkate alması gerekmektedir (Gök, 2020). İş motivasyonu içsel ve dışsal olmak üzere iki ana gruba ayrılmaktadır. İçsel motivasyon Ertürk ve Aydın (2017)'a göre kişisel hedeflere ulaşmak arzusundan meydana gelen enerji olarak ifade edilmektedir. Dışsal motivasyon Ertürk (2016)'e göre bireyin içinde bulduğu iş ve sosyal çevresi dışsal motivasyonun kaynağı olarak görülmektedir. Dışsal motivasyonun örgütsel ve sosyal olmak üzere iki boyutu bulunmaktadır. Sosyal motivasyon araçları; arkadaşlık, yardımseverlik, yöneticiler tarafından çalışanlara sağlanan manevi destek olarak sıralanırken, örgütsel boyutta yararlanılan dışsal motivasyon araçları ise, çalışılan ortam içerisindeki kaynakların yeterliliği, adaletli ücret dağııımı, ikramiyeler ve iş güvencesi olarak sıralanmaktadır (Ersarı ve Naktiyok, 2012).

Aralık 2019 itibariyle Çin'in Wuhan kentinde ortaya çıkan yeni tip korona virüs (Covid-19), dünya üzerinde ölümcül sonuçlara neden olmuştur. Bu salgın Dünya Sağlık Örgütü tarafından "Pandemi" olarak ilan edilmiştir. Başta sağlık sektörü olmak üzere birçok sektörü etkileyen korona virüs gerek spor gerekse iş yaşamını da derinden etkilemiştir.

Bazı kamu kurum ve kuruluşlarında olduğu gibi Gençlik Spor İl Müdürlüklerinde de çalışanların, çalışma koşullarını ev ortamına taşımalarını ve bireylerin yapması gereken işleri dijital ortamda, çevrimiçi çalışarak yapmalarını zorunlu kıımıştır. Ancak çevrimiçi çalışma hayatına geçiş çok kolay olmamakla birlikte, teknolojik ve bireye bağlı olarak değişkenlikler gösteren problemleri de beraberinde getirmiştir. Korona virüs salgını sürecinde bireyin çalışı̆̆ı kurumun ve pozisyonun çevrimiçi çalışma koşullarına uygun olup olmaması, çalışma hayatındaki pozisyonu ve statüsü, teknolojik cihazları kullanabilmesi ve bu cihazlara erişim sorunları, çalışan kişinin iş motivasyonunu etkilemiştir.

Bazı kamu kurum ve kuruluşlarının esnek çalışma saatlerine geçmesiyle birlikte çalışan bireyler işlerini kimi zaman çevrimiçi olarak, kimi zaman ise iş yerinde 

195.

çalışarak yapmaya başlamışlardır. İ̧̧ yerlerinde çalışanların, Covid-19 virüsünün bulaşıcı etkilerinden korunmaları amacı ile birçok tedbir alınsa da insanların, hastalığa yakalanma riskinden dolayı kaygı düzeylerinde değişikliklere sebep olmuştur. Uluç ve Duman (2020) tarafından yapılan bir araştırmada Covid-19 pandemi döneminde Gençlik ve Spor İı Müdürlüğü çalışanlarının kaygı düzeylerinin yüksek olduğu sonucuna ulaşıımıştır. Gençlik ve Spor İ Müdürlüğü çalışanlarının kaygı düzeylerinde meydana gelen bu değişikliğin çalışan kişilerin iş motivasyonu düzeylerine etki edebileceği düşünülmüştür. Tüm bunlar göz önüne alındığında Gençlik ve Spor II Müdürlükleri çalışanlarının, Covid-19 Pandemi sürecinde iş motivasyonlarının ve kaygı düzeylerinin incelenmesi çalışmanın konusunu oluşturmaktadır.

Covid-19 Pandemi sürecinde Manisa, İzmir ve Aydın Gençlik ve Spor II Müdürlüklerinde çalışan bireylerin iş motivasyonu ve kaygı düzeylerinin incelenmesi amacıyla yapılan bu araştırmanın önemi; Covid-19 Pandemi sürecinde Gençlik ve Spor II Müdürlüklerinde çalışan bireylerin iş motivasyonları ve kaygı düzeyleri incelenerek elde edilen sonuçlar doğrultusunda çözüm önerilerinde bulunmak ve alan ile ilgili yapılan çalışmalara katkı sağlamaktır.

\section{Yöntem}

\section{Araştırmanın Modeli}

Çalışmada, nicel araştırma yöntemi kullanılmıştır. Nicel araştırma yöntemi, sınırlı sayıda sorular sorularak katıımcılardan toplanan verilerin istatistiksel analizler kullanılarak örneklemden evrene genelleştirilebilir yorumlar elde edilmesini sağlamaktadır (Mazlum ve Atalay, 2017). Çalışma, nicel araştırma modellerinden tarama modeli ile yürütülmüştür. Tarama modeli, geçmişte veya var olan durumu var olduğu şekliyle betimleyen, tanımlayan araşııma yaklaşımıdır (Karaşar ve Öğülmüş, 2016).

\section{Evren ve Örneklem}

Covid-19 Pandemi Sürecinde Manisa, İzmir ve Aydın Gençlik ve Spor II Müdürlüklerinde çalışan bireylerin iş motivasyonu ve kaygı düzeylerinin incelenmesi amacıyla yapılan bu araştırmada basit tesadüfi örnekleme yöntemi kullanılmıştır. Araştırmanın evrenini Manisa, İzmir ve Aydın Gençlik Spor ve İ Müdürlüğü 
Bulut, Ç. ve Duman, S. (2021). Covid-19 Pandemi Sürecinde Gençlik ve Spor İl Müdürlükleri Çalışanlarının İş Motivasyonları ve Kayg1 Düzeylerinin İncelenmesi. Gaziantep Üniversitesi Spor Bilimleri Dergisi, 6(2), 115195.

çalışanları oluşturmaktadır. Araştırmanın örneklemini ise Manisa, İzmir ve Aydın Gençlik ve Spor İı Müdürlüklerinde çalışan 510 gönüllü katılımcı oluşturmaktadır.

\section{Verilerin Toplanması}

Covid-19 Pandemi Sürecinde Manisa, İzmir ve Aydın Gençlik ve Spor İ Müdürlüklerinde çalışan bireylerin İş motivasyonu ve kaygı düzeylerinin incelenmesi amacıyla yapılan bu araştırmada İş motivasyonu ve Durumluk Sürekli kaygı ölçeği kullanılmıştır. Manisa, İzmir ve Aydın Gençlik ve Spor İı Müdürlüğünde çalışan 510 gönüllü katılımcıya, çevrimiçi ortamda ulaşılmıştır.

Marc ve diğerleri tarafından 1993 yılında geliştirilen İş Motivasyonu Ölçeği, 2013 yılında Yılmaz (2012) tarafından Türkçeye geçerlik ve güvenirlik çalışması yapılarak uyarlanmıştır. 5'li likert tipten oluşan iş motivasyonu ölçeği 31 soru ve 6 alt boyuttan oluşmaktadır. Ölçek içsel ve dışsal motivasyon $(2,6,10,17,21,25,31)$, uyarıma özgü içsel motivasyon $(1,16,24,26,27,29)$, sonraya bırakılmış içsel motivasyon $(8,15,23,30)$, içsel motivasyon-dış düzenleme $(13,20,28)$, bilgi ve gelişime özgü içsel motivasyon $(7,11,12,14)$ ve sosyal statü ve özgüvene dayalı içsel motivasyon $(3,4,5)$ alt boyutları hakkında bilgi sağlamaktadır. Çalışmada liş motivasyonu toplam ölçek Cronbach Alpha iç tutarlılık katsayısı 0,91; alt boyutlara ilişkin iç tutarlılık katsayıları içsel ve dışsal motivasyon 0,86, uyarıma özgü içsel motivasyon 0,86 , sonraya bırakılmış içsel motivasyon 0,79 , içsel motivasyon-dış düzenleme 0,71 , bilgi ve gelişime özgü içsel motivasyon 0,80 , sosyal statü ve özgüvene dayalı içsel motivasyon 0,56 olarak hesaplanmıştır. Yıldız ve Uzunsakal (2018)'a göre Cronbach Alpha değerinin 0.60 üzerinde oldukça güvenilir, 0.80 üzerinde ise yüksek güvenilir olduğu kabul edilmektedir. Ölçeğin toplam puanı ve alt boyut puanlarına ilişkin iç tutarlılık katsayılarına göre ölçeğin genel anlamda güvenilir olduğu söylenebilmektedir.

1970 yılında Spielberger ve diğerleri tarafından geliştirilen durumluk-sürekli kaygı ölçeği, Türkçeye 1983 yılında geçerlilik ve güvenilirlik çalışmaları yapılarak Öner ve Le Compte tarafından uyarlanmıştır. Durumluk kaygı ölçeğinde ifade edilen duygu veya davranışlar o anlık hissedilme derecesine göre 1 (Hiç)'den başlayarak 4 (Tamamıyla)'e kadar numaralandırılan ve 4'lü likert tipten oluşan ölçektir. Sürekli kaygı ölçeği ise 1 (Hemen hemen hiçbir zaman)'den başlayarak 4 (Hemen hemen her zaman)'e kadar sıralanan 4'lü likert tipte oluşan ölçektir. Durumluk kaygı 
ölçeğinde $1,2,5,8,10,11,15,16,19$ ve 20 numaralı maddeler sürekli kaygı ölçeğinde, durumluk kaygı ölçeğinde 21, 26, 27, 30, 33, 36 ve 39 tersine dönmüş ifadelerdir. Her bir ölçekte 20'şer soru bulunan Durumluk-Süreki kaygı ölçeği toplam 40 sorudan oluşmaktadır. Çalışmada Durumluk kaygı ölçeği Cronbach Alpha iç tutarlılık katsayısı 0,91; sürekli kaygı ölçeği Cronbach Alpha iç tutarlııı katsayısı 0,85 olarak hesaplanmıştır ve ölçeğin yüksek güvenilir olduğu söylenebilmektedir.

\section{Verilerin analizi}

Araştırmadan elde edilen verilerin analizinde SPSS 26.0 paket programı kullanılmıştır. Analiz seçiminde, verilerin normal dağılım gösterip göstermediği normal dağılım varsayımları, Kolmogorov-Smirnov Testi ile Box Plot ve histogram grafikleri incelenerek belirlenmiştir. Kolmogorov-Smirnov Testi sonucunda, İş Motivasyonu Ölçeğinden elde edilen içsel ve dışsal motivasyon [D=0.09; $p<0.05]$, uyarıma özgü içsel motivasyon $[D=0.12 ; p<0.05]$, sonraya bırakılmış içsel motivasyon $[D=0.13$; $p<0.05]$, içsel motivasyon-dış düzenleme $[\mathrm{D}=0.17 ; p<0.05]$, bilgi ve gelişime özgü içsel motivasyon $[D=0.13 ; p<0.05]$, sosyal statü ve özgüvene dayalı motivasyon $[D=0.13 ; p<0.05]$ alt boyut puanlarının ve Durumluk Kaygı $[D=0.08 ; p<0.05]$ ve Sürekli Kaygı Ölçeğinden $[D=0.05 ; p<0.05]$ elde edilen toplam puanların normal dağılım göstermediği tespit edilmiştir. Bu bağlamda ikiden fazla grubun karşılaştırılmasında parametrik olmayan testlerden Kruskal-Wallis Testi kullanılmıştır. İkiden fazla grubun karşılaştırımasında farklııık tespit edilen durumda, gruplar ikili karşılaştırmalar ile test edilmiş ve Bonferroni düzeltmesi yapılmıştır. İş motivasyonu ve kaygı düzeyleri arasındaki ilişkinin belirlenmesinde Spearman Korelasyon Analizi kullanılmıştır.

\section{Bulgular}

Çalışmaya, 170'i $(\% 33,3)$ Aydın, 191'i $(\% 37,5)$ Manisa ve 149'u $(\% 29,2)$ İzmir illerinden toplam 510 Gençlik ve Spor İ Müdürlüğü çalışanı katılmıştır. Katııımcıların 324 'ü $(\% 63,5)$ erkek, 186’sı $(\% 36,5)$ kadındır. Katıımcıların 243'ü $(\% 47,6) 35$ yaş ve altı, 206'sı (\%40,4) 36-45 yaş arası ve 61'i (\%12) 46 yaş ve üzeridir. Katıımcıların 178 'i $(34,9)$ Lise, 46'sı $(\% 9,0)$ Ön Lisans, 254'ü $(\% 49,8)$ Lisans ve 32'si $(\% 6,3)$ Yüksek Lisans-Doktora mezunudur. Katılımcıların 142'si $(\% 27,8) 4$ yıl ve altı, 138'i $(\% 27,1) 5-7$ yıl arası ve 230'u (\%45,1) 8 yıl ve üzeri mesleki kıdeme sahiptir. 
Bulut, Ç. ve Duman, S. (2021). Covid-19 Pandemi Sürecinde Gençlik ve Spor İl Müdürlükleri Çalışanlarının İş Motivasyonları ve Kaygı Düzeylerinin İncelenmesi. Gaziantep Üniversitesi Spor Bilimleri Dergisi, 6(2), 115195.

Tablo 1. Çalışanların İş Motivasyonlarının ve Durumluk-Sürekli Kaygılarının Çalışılan II Değişkenine Göre Kruskal-Wallis Test Sonuçları

\begin{tabular}{|c|c|c|c|c|c|c|c|}
\hline Ölçekler & & $\begin{array}{l}\text { Çalışılan } \\
\text { il }\end{array}$ & $\mathbf{N}$ & Ort. & Ss & $x^{2}$ & p \\
\hline \multirow{18}{*}{$\begin{array}{l}\text { İş } \\
\text { Motivasyonu } \\
\text { Ölçeği }\end{array}$} & \multirow{3}{*}{$\begin{array}{l}\text { İçsel ve Dışsal } \\
\text { Motivasyon }\end{array}$} & Aydın & 170 & 28.39 & 4.96 & \multirow{3}{*}{5.31} & \multirow{3}{*}{0.07} \\
\hline & & Manisa & 191 & 29.70 & 4.01 & & \\
\hline & & İzmir & 149 & 29.11 & 4.59 & & \\
\hline & \multirow{3}{*}{$\begin{array}{l}\text { Uyarıma Özgü } \\
\text { İçsel Motivasyon }\end{array}$} & Aydın & 170 & 22.57 & 4.73 & \multirow{3}{*}{4.65} & \multirow{3}{*}{0.09} \\
\hline & & Manisa & 191 & 23.75 & 4.09 & & \\
\hline & & İzmir & 149 & 22.90 & 4.60 & & \\
\hline & \multirow{3}{*}{$\begin{array}{l}\text { Sonraya } \\
\text { Bırakılmış İçsel } \\
\text { Motivasyon }\end{array}$} & Aydın & 170 & 14.90 & 3.41 & \multirow{3}{*}{4.02} & \multirow{3}{*}{0.13} \\
\hline & & Manisa & 191 & 14.83 & 3.34 & & \\
\hline & & İzmir & 149 & 14.30 & 3.42 & & \\
\hline & \multirow{3}{*}{$\begin{array}{l}\text { İçsel } \\
\text { Motivasyon-Dış } \\
\text { Düzenleme }\end{array}$} & Aydın & 170 & 11.24 & 2.30 & \multirow{3}{*}{25.12} & \multirow{3}{*}{0.00} \\
\hline & & Manisa & 191 & 9.90 & 2.51 & & \\
\hline & & İzmir & 149 & 10.32 & 2.71 & & \\
\hline & \multirow{3}{*}{$\begin{array}{l}\text { Bilgi ve Gelişime } \\
\text { Özgü } \\
\text { İçsel Motivasyon }\end{array}$} & Aydın & 170 & 14.46 & 3.31 & \multirow{3}{*}{3.38} & \multirow{3}{*}{0.18} \\
\hline & & Manisa & 191 & 15.03 & 3.27 & & \\
\hline & & İzmir & 149 & 14.55 & 3.27 & & \\
\hline & \multirow{3}{*}{$\begin{array}{l}\text { Sosyal Statü ve } \\
\text { Özgüvene Dayalı } \\
\text { Motivasyon }\end{array}$} & Aydın & 170 & 10.55 & 2.53 & \multirow{3}{*}{1.82} & \multirow{3}{*}{0.40} \\
\hline & & Manisa & 191 & 10.35 & 2.56 & & \\
\hline & & İzmir & 149 & 10.25 & 2.44 & & \\
\hline \multirow{6}{*}{$\begin{array}{l}\text { Durumluk- } \\
\text { Sürekli Kaygı } \\
\text { Ölçeği }\end{array}$} & \multirow{3}{*}{ Durumluk Kaygı } & Aydın & 170 & 33.25 & 10.11 & \multirow{3}{*}{1.69} & \multirow{3}{*}{0.42} \\
\hline & & Manisa & 191 & 32.60 & 9.00 & & \\
\hline & & İzmir & 149 & 33.47 & 8.17 & & \\
\hline & \multirow{3}{*}{ Sürekli Kaygı } & Aydın & 170 & 38.21 & 7.61 & \multirow{3}{*}{1.94} & \multirow{3}{*}{0.37} \\
\hline & & Manisa & 191 & 37.71 & 7.31 & & \\
\hline & & İzmir & 149 & 38.55 & 7.36 & & \\
\hline
\end{tabular}

Tablo 1 incelendiğinde, çalışılan il değişkenine göre içsel motivasyon-dış düzenleme alt boyut puanının istatistiksel olarak anlamlı farklılaştığı sonucuna ulaşılmıştır $\left(x^{2}=\right.$ 25.12; $p<0.05)$. İçsel motivasyon-dış düzenleme alt boyut puanında, Aydın ile Manisa ve İzmir ilinde çalışanlar arasında istatistiksel olarak anlamlı farklılık gözlenmiştir. Aydın ilinde çalışanların içsel motivasyon-dış düzenleme puanı (11.24), Manisa ilinde çalışanlardan (9.90) ve İzmir ilinde çalışanlardan (10.32) anlamlı şekilde yüksektir.

Çalışanların durumluk kaygı ( $\left.x^{2}=1.69 ; p>0.05\right)$ ve sürekli kaygı ( $\left.x^{2}=1.94 ; p>0.05\right)$ düzeylerinin çalışılan il değişkenine göre istatistiksel olarak anlamlı farklılaşmadığı tespit edilmiştir. 
Bulut, Ç. ve Duman, S. (2021). Covid-19 Pandemi Sürecinde Gençlik ve Spor İl Müdürlükleri Çalışanlarının İş Motivasyonları ve Kaygı Düzeylerinin İncelenmesi. Gaziantep Üniversitesi Spor Bilimleri Dergisi, 6(2), 115195.

Tablo 2. Çalışanların İş Motivasyonlarının ve Durumluk-Sürekli Kaygılarının Eğitim Durumu Değişkenine Göre Kruskal-Wallis Test Sonuçları

\begin{tabular}{|c|c|c|c|c|c|c|c|}
\hline Ölçekler & & $\begin{array}{l}\text { Eğitim } \\
\text { Durumu }\end{array}$ & $\mathbf{N}$ & Ort. & Ss & $x^{2}$ & p \\
\hline \multirow{26}{*}{$\begin{array}{l}\text { Işs } \\
\text { Motivasyonu } \\
\text { Ölçeği }\end{array}$} & \multirow{4}{*}{$\begin{array}{l}\text { İçsel ve } \\
\text { Dişsal } \\
\text { Motivasyon }\end{array}$} & Lise & 178 & 28.80 & 4.14 & \multirow{4}{*}{12.07} & \multirow{4}{*}{0.00} \\
\hline & & Ön Lisans & 46 & 29.50 & 4.82 & & \\
\hline & & Lisans & 254 & 28.92 & 4.80 & & \\
\hline & & $\begin{array}{l}\text { Yüksek } \\
\text { Lisans- } \\
\text { Doktora }\end{array}$ & 32 & 31.50 & 3.35 & & \\
\hline & \multirow{4}{*}{$\begin{array}{l}\text { Uyarıma } \\
\text { Özgü Içsel } \\
\text { Motivasyon }\end{array}$} & Lise & 178 & 22.59 & 4.17 & \multirow{4}{*}{10.46} & \multirow{4}{*}{0.01} \\
\hline & & Ön Lisans & 46 & 23.42 & 3.53 & & \\
\hline & & Lisans & 254 & 23.19 & 4.84 & & \\
\hline & & $\begin{array}{l}\text { Yüksek } \\
\text { Lisans- } \\
\text { Doktora }\end{array}$ & 32 & 24.94 & 3.91 & & \\
\hline & \multirow{5}{*}{$\begin{array}{l}\text { Sonraya } \\
\text { Bırakılmış } \\
\text { İçsel } \\
\text { Motivasyon }\end{array}$} & Lise & 178 & 14.89 & 3.13 & \multirow{5}{*}{5.09} & \multirow{5}{*}{0.16} \\
\hline & & Ön Lisans & 46 & 15.60 & 2.91 & & \\
\hline & & Lisans & 254 & 14.44 & 3.60 & & \\
\hline & & Yüksek & & & & & \\
\hline & & $\begin{array}{l}\text { Lisans- } \\
\text { Doktora }\end{array}$ & 32 & 14.43 & 3.54 & & \\
\hline & \multirow{5}{*}{$\begin{array}{l}\text { İçsel } \\
\text { Motivasyon- } \\
\text { Dış } \\
\text { Düzenleme }\end{array}$} & Lise & 178 & 11.00 & 2.23 & \multirow{5}{*}{17.62} & \multirow{5}{*}{0.00} \\
\hline & & Ön Lisans & 46 & 10.97 & 2.25 & & \\
\hline & & Lisans & 254 & 10.14 & 2.74 & & \\
\hline & & Yüksek & & & & & \\
\hline & & $\begin{array}{l}\text { Lisans- } \\
\text { Doktora }\end{array}$ & 32 & 9.34 & 2.59 & & \\
\hline & \multirow{4}{*}{$\begin{array}{l}\text { Bilgi ve } \\
\text { Gelişime } \\
\text { Özgü } \\
\text { İçsel } \\
\text { Motivasyon }\end{array}$} & Lise & 178 & 14.43 & 3.08 & \multirow{4}{*}{7.11} & \multirow{4}{*}{0.06} \\
\hline & & Ön Lisans & 46 & 15.17 & 2.62 & & \\
\hline & & Lisans & 254 & 14.64 & 3.55 & & \\
\hline & & $\begin{array}{l}\text { Yüksek } \\
\text { Lisans- } \\
\text { Doktora }\end{array}$ & 32 & 16.00 & 2.74 & & \\
\hline & \multirow{4}{*}{$\begin{array}{l}\text { Sosyal } \\
\text { Statü ve } \\
\text { Özgüvene } \\
\text { Dayalı } \\
\text { Motivasyon }\end{array}$} & Lise & 178 & 11.11 & 2.27 & \multirow{4}{*}{31.01} & \multirow{4}{*}{0.00} \\
\hline & & Ön Lisans & 46 & 11.00 & 2.08 & & \\
\hline & & Lisans & 254 & 9.85 & 2.60 & & \\
\hline & & $\begin{array}{l}\text { Yüksek } \\
\text { Lisans- } \\
\text { Doktora }\end{array}$ & 32 & 9.75 & 2.55 & & \\
\hline \multirow{9}{*}{$\begin{array}{l}\text { Durumluk- } \\
\text { Sürekli } \\
\text { Kaygı Ölçeği }\end{array}$} & \multirow{5}{*}{$\begin{array}{l}\text { Durumluk } \\
\text { Kaygı }\end{array}$} & Lise & 178 & 31.19 & 8.23 & \multirow{5}{*}{13.82} & \multirow{5}{*}{0.00} \\
\hline & & Ön Lisans & 46 & 31.91 & 8.35 & & \\
\hline & & Lisans & 254 & 34.53 & 9.54 & & \\
\hline & & Yüksek & & & & & \\
\hline & & $\begin{array}{l}\text { Lisans- } \\
\text { Doktora }\end{array}$ & 32 & 33.65 & 10.24 & & \\
\hline & \multirow{4}{*}{$\begin{array}{l}\text { Sürekli } \\
\text { Kaygı }\end{array}$} & Lise & 178 & 37.99 & 7.14 & \multirow{4}{*}{4.12} & \multirow{4}{*}{0.24} \\
\hline & & Ön Lisans & 46 & 36.45 & 6.88 & & \\
\hline & & Lisans & 254 & 38.64 & 7.70 & & \\
\hline & & $\begin{array}{l}\text { Yüksek } \\
\text { Lisans- } \\
\text { Doktora }\end{array}$ & 32 & 37.12 & 7.29 & & \\
\hline
\end{tabular}

Tablo 2 incelendiğinde, eğitim durumu değişkenine göre içsel ve dışsal motivasyon, uyarıma özgü içsel motivasyon, içsel motivasyon-dış düzenleme, sosyal 
Bulut, Ç. ve Duman, S. (2021). Covid-19 Pandemi Sürecinde Gençlik ve Spor İl Müdürlükleri Çalışanlarının İş Motivasyonları ve Kayg1 Düzeylerinin İncelenmesi. Gaziantep Üniversitesi Spor Bilimleri Dergisi, 6(2), 115195.

statü ve özgüvene dayalı motivasyon alt boyut puanlarının istatistiksel olarak anlamlı farklılaştığı sonucuna ulaşılmıştır $(p<0.05)$.

İçsel ve dışsal motivasyon alt boyut puanında, yüksek lisans-doktora mezunu çalışanlar ile lise mezunu ve lisans mezunu çalışanlar arasında istatistiksel olarak anlamlı farklılık gözlenmiştir. Yüksek lisans-doktora mezunu çalışanların içsel ve dışsal motivasyon puanı (31.50), lise mezunu çalışanlardan (28.80) ve lisans mezunu çalışanlardan (28.92) anlamlı şekilde yüksektir.

Uyarıma özgü içsel motivasyon alt boyut puanında, yüksek lisans-doktora mezunu çalışanlar ile lise mezunu çalışanlar arasında istatistiksel olarak anlamlı farklılık gözlenmiştir. Yüksek lisans-doktora mezunu çalışanların uyarıma özgü içsel motivasyon puanı (24.94), lise mezunu çalışanlardan (22.59) anlamlı şekilde yüksektir.

İçsel motivasyon-dış düzenleme alt boyut puanında, lise mezunu çalışanlar ile lisans mezunu ve yüksek lisans-doktora mezunu çalışanlar arasında; ön lisans mezunu çalışanlar ile yüksek lisans-doktora mezunu çalışanlar arasında istatistiksel olarak anlamlı farklılık gözlenmiştir. Lise mezunu çalışanların içsel motivasyon-dış düzenleme puanı (11.00), lisans mezunu çalışanlardan (10.14) ve yüksek lisansdoktora mezunu çalışanlardan (9.34) anlamlı şekilde yüksektir. Ayrıca ön lisans mezunu çalışanların içsel motivasyon-dış düzenleme puanı (10.97), yüksek lisansdoktora mezunu çalışanlardan (9.34) anlamlı şekilde yüksektir.

Sosyal statü ve özgüvene dayalı motivasyon alt boyut puanında, lise mezunu çalışanlar ile lisans mezunu ve yüksek lisans-doktora mezunu çalışanlar arasında; lisans mezunu çalışanlar ile ön lisans mezunu çalışanlar arasında istatistiksel olarak anlamlı farklılık gözlenmiştir. Lise mezunu çalışanların sosyal statü ve özgüvene dayalı motivasyon puanı (11.11), lisans mezunu çalışanlardan (9.85) ve yüksek lisans-doktora mezunu çalışanlardan (9.75) anlamlı şekilde yüksektir.

Çalışanların durumluk kaygı düzeylerinin eğitim durumu değişkenine göre istatistiksel olarak anlamlı farklılaştığı sonucuna ulaşılmıştır $(p<0.05)$. Durumluk kaygı düzeyinde, lise mezunu çalışanlar ile lisans mezunu çalışanlar arasında istatistiksel olarak anlamlı farklılık gözlenmiştir. Lisans mezunu çalışanların durumluk kaygı düzeyleri (34.53), lise mezunu çalışanlardan (31.19) anlamlı şekilde yüksektir. 
Bulut, Ç. ve Duman, S. (2021). Covid-19 Pandemi Sürecinde Gençlik ve Spor İl Müdürlükleri Çalışanlarının İş Motivasyonları ve Kayg1 Düzeylerinin İncelenmesi. Gaziantep Üniversitesi Spor Bilimleri Dergisi, 6(2), 115195.

Tablo 3. Çalışanların İş Motivasyonlarının ve Durumluk-Sürekli Kaygılarının Mesleki Kıdem Değişkenine Göre Kruskal-Wallis Test Sonuçları

\begin{tabular}{|c|c|c|c|c|c|c|c|}
\hline Ölçekler & & $\begin{array}{l}\text { Mesleki } \\
\text { Kıdem }\end{array}$ & $\mathbf{N}$ & Ort. & Ss & $x^{2}$ & $\mathbf{p}$ \\
\hline \multirow{18}{*}{$\begin{array}{l}\text { İş } \\
\text { Motivasyonu } \\
\text { Ölçeği }\end{array}$} & \multirow{3}{*}{$\begin{array}{l}\text { İçsel ve } \\
\text { Dışsal } \\
\text { Motivasyon }\end{array}$} & 4 yıl ve altı & 142 & 29.71 & 4.45 & \multirow{3}{*}{4.40} & \multirow{3}{*}{0.11} \\
\hline & & $5-7$ yıl & 138 & 28.82 & 4.87 & & \\
\hline & & $\begin{array}{lll}8 \text { yıl } & \text { ve } \\
\text { üzeri } & \\
\end{array}$ & 230 & 28.87 & 4.36 & & \\
\hline & \multirow{3}{*}{$\begin{array}{l}\text { Üyarıma } \\
\text { Özgü İçsel } \\
\text { Motivasyon }\end{array}$} & 4 yıl ve altı & 142 & 23.72 & 4.23 & \multirow{3}{*}{3.28} & \multirow{3}{*}{0.19} \\
\hline & & $5-7 \mathrm{yll}$ & 138 & 22.98 & 4.49 & & \\
\hline & & $\begin{array}{lll}8 & \text { yıl } & \text { ve } \\
\text { üzeri } & \end{array}$ & 230 & 22.81 & 4.61 & & \\
\hline & \multirow{3}{*}{$\begin{array}{l}\text { Sonraya } \\
\text { Bırakılmış } \\
\text { İçsel } \\
\text { Motivasyon }\end{array}$} & 4 yıl ve altı & 142 & 15.23 & 3.45 & \multirow{3}{*}{6.39} & \multirow{3}{*}{0.04} \\
\hline & & $5-7$ yıl & 138 & 14.75 & 3.12 & & \\
\hline & & $\begin{array}{l}8 \text { yıl ve } \\
\text { üzeri }\end{array}$ & 230 & 14.34 & 3.47 & & \\
\hline & \multirow{3}{*}{$\begin{array}{l}\text { İçsel } \\
\text { Motivasyon- } \\
\text { Dış } \\
\text { Düzenleme }\end{array}$} & 4 yıl ve altı & 142 & 10.09 & 2.53 & \multirow{3}{*}{7.31} & \multirow{3}{*}{0.02} \\
\hline & & $5-7 \mathrm{yll}$ & 138 & 10.90 & 2.46 & & \\
\hline & & $\begin{array}{lll}8 & \text { yıl } & \text { ve } \\
\text { üzeri } & \end{array}$ & 230 & 10.44 & 2.61 & & \\
\hline & \multirow{3}{*}{$\begin{array}{l}\text { Bilgi ve } \\
\text { Gelişime } \\
\text { Özgü } \\
\text { İçsel } \\
\text { Motivasyon }\end{array}$} & 4 yıl ve altı & 142 & 15.23 & 3.12 & \multirow[b]{3}{*}{4.6} & \multirow{3}{*}{0.09} \\
\hline & & $5-7$ yıl & 138 & 14.50 & 3.20 & & \\
\hline & & $\begin{array}{l}8 \text { yıl ve } \\
\text { üzeri }\end{array}$ & 230 & 14.49 & 3.41 & & \\
\hline & \multirow{3}{*}{$\begin{array}{l}\text { Sosyal } \\
\text { Statü ve } \\
\text { Özgüvene } \\
\text { Dayalı } \\
\text { Motivasyon }\end{array}$} & 4 yıl ve altı & 142 & 10.62 & 2.48 & \multirow[b]{3}{*}{3.38} & \multirow[b]{3}{*}{0.18} \\
\hline & & $5-7$ yıl & 138 & 10.51 & 2.49 & & \\
\hline & & $\begin{array}{l}8 \text { yıl ve } \\
\text { üzeri }\end{array}$ & 230 & 10.17 & 2.54 & & \\
\hline \multirow{6}{*}{$\begin{array}{l}\text { Durumluk- } \\
\text { Sürekli } \\
\text { Kaygı Ölçeği }\end{array}$} & \multirow{3}{*}{$\begin{array}{l}\text { Durumluk } \\
\text { Kaygı }\end{array}$} & 4 yıl ve altı & 142 & 32.26 & 9.07 & \multirow{3}{*}{1.93} & \multirow{3}{*}{0.38} \\
\hline & & $5-7 \mathrm{yll}$ & 138 & 33.22 & 9.27 & & \\
\hline & & $\begin{array}{lll}8 & \text { yıl } & \text { ve } \\
\text { üzeri } & \end{array}$ & 230 & 33.49 & 9.14 & & \\
\hline & \multirow{3}{*}{$\begin{array}{l}\text { Sürekli } \\
\text { Kaygı }\end{array}$} & 4 yıl ve altı & 142 & 37.49 & 7.86 & \multirow{3}{*}{0.66} & \multirow{3}{*}{0.71} \\
\hline & & $5-7$ yıl & 138 & 38.32 & 7.49 & & \\
\hline & & $\begin{array}{l}8 \text { yıl } \\
\text { üzeri }\end{array}$ & 230 & 38.40 & 7.11 & & \\
\hline
\end{tabular}

Tablo 3'e göre, mesleki kıdem değişkenine sonraya bırakılmış içsel motivasyon, içsel motivasyon-dış düzenleme alt boyut puanlarının istatistiksel olarak anlamlı farklılaştığı sonucuna ulaşılmıştır $(p<0.05)$. Sonraya bırakılmış içsel motivasyon alt boyut puanında, 4 yıl ve altı mesleki kıdeme sahip çalışanlar ile 8 yıl ve üzeri mesleki kıdeme sahip çalışanlar arasında istatistiksel olarak anlamlı farklılık gözlenmiştir. 4 yıl ve altı mesleki kıdeme sahip çalışanların sonraya bırakılmış içsel motivasyon puanı (15.23), 8 yıl ve üzeri mesleki kıdeme sahip çalışanlardan (14.34) anlamlı şekilde yüksektir.

İçsel motivasyon-dış düzenleme alt boyut puanında, 4 yıl ve altı mesleki kıdeme sahip çalışanlar ile 5-7 yıl mesleki kıdeme sahip çalışanlar arasında istatistiksel olarak anlamlı farklılık gözlenmiştir. 5-7 yıl mesleki kıdeme sahip çalışanların içsel 
motivasyon-dış düzenleme puanı (10.90), 4 yıl ve altı mesleki kıdeme sahip çalışanlardan (10.09) anlamlı şekilde yüksektir. Çalışanların durumluk kaygı ve sürekli kaygı düzeylerinin mesleki kıdem değişkenine göre istatistiksel olarak anlamlı farklılaşmadığı tespit edilmiştir ( $p>0.05)$.

Ayrıca çalışanların iş motivasyonlarının cinsiyet değişkenine göre uyarıma özgü içsel motivasyon alt boyut puanının istatistiksel olarak anlamlı farklılaşığı sonucuna ulaşıımışıı $(p<0.05)$. Erkek çalışanların uyarıma özgü içsel motivasyon puanı (23.40), kadın çalışanlardan (22.60) anlamlı şekilde yüksektir. Çalışanların durumluk kaygı ve sürekli kaygı düzeylerinin cinsiyet değişkenine göre istatistiksel olarak anlamlı farklılaşmadığı tespit edilmiştir $(p>0.05)$. Çalışanların iş motivasyonları ve durumluk-sürekli kaygılarının yaş değişkenine göre istatistiksel olarak anlamlı farklılaşmadığı sonucuna ulaşıımışıı ( $p>0.05)$.

Tablo 4. İs Motivasyonu ve Kaygı Düzeyi Arasındaki Iliş̧i

\begin{tabular}{|c|c|c|c|c|c|c|c|c|}
\hline & 1 & 2 & 3 & 4 & 5 & 6 & 7 & 8 \\
\hline 1.Durumluk Kaygı & & $0.64^{\star *}$ & $\begin{array}{l}- \\
0.39 \\
* *\end{array}$ & $-0.33^{* *}$ & $0.35^{\star *}$ & -0.03 & $\overline{0.33^{* *}}$ & $-0.15^{\star *}$ \\
\hline 2.Sürekli Kaygı & & & $\overline{0}$ & $-0.24^{* *}$ & $\overline{0.15^{\star *}}$ & 0.04 & $\overline{0.20 * *}$ & 0.03 \\
\hline $\begin{array}{l}\text { 3. İçsel ve Dışsal } \\
\text { Motivasyon }\end{array}$ & & & & $0.45^{\star \star}$ & $0.34^{\star *}$ & -0.06 & 0.39 ** & $0.15^{\star *}$ \\
\hline $\begin{array}{l}\text { 4.Uyarıma Özgü İçsel } \\
\text { Motivasyon }\end{array}$ & & & & & $0.65^{\star *}$ & 0.03 & $0.76^{* \star}$ & $0.34^{\star \star}$ \\
\hline $\begin{array}{l}\text { 5. Sonraya Bırakılmış } \\
\text { İçsel Motivasyon }\end{array}$ & & & & & & $\begin{array}{l}0.16 \\
* \star\end{array}$ & $0.64^{\star \star}$ & $0.39 * *$ \\
\hline $\begin{array}{l}\text { 6. İçsel Motivasyon- } \\
\text { Dış Düzenleme }\end{array}$ & & & & & & & 0.05 & $0.40^{* *}$ \\
\hline $\begin{array}{l}\text { 7. Bilgi ve Gelişime } \\
\text { Özgü İçsel } \\
\text { Motivasyon }\end{array}$ & & & & & & & & $0.39 * *$ \\
\hline $\begin{array}{l}\text { 8. Sosyal Statü ve } \\
\text { Özgüvene Dayalı } \\
\text { İçsel Motivasyon }\end{array}$ & & & & & & & & \\
\hline
\end{tabular}

**Korelasyon 0.01 düzeyinde anlamlıdır.

İş motivasyonu ve kaygı düzeyleri arasındaki ilişkinin belirlenmesinde Spearman Korelasyon Analizi kullanılmıştır.

Durumluk kaygı ile "içsel ve dışsal motivasyon", "uyarıma özgü içsel 
Bulut, Ç. ve Duman, S. (2021). Covid-19 Pandemi Sürecinde Gençlik ve Spor İl Müdürlükleri Çalışanlarının İş Motivasyonları ve Kayg1 Düzeylerinin İncelenmesi. Gaziantep Üniversitesi Spor Bilimleri Dergisi, 6(2), 115195.

motivasyon", "sonraya bırakılmış içsel motivasyon", "bilgi ve gelişime özgü içsel motivasyon" arasında negatif ve zayıf düzeyde anlamlı ilişki tespit edilmiştir. Durumluk kaygı ile "sosyal statü ve özgüvene dayalı içsel motivasyon" arasında negatif ve çok zayıf düzeyde anlamlı ilişki tespit edilmiştir. Durumluk kaygı ile "içsel motivasyon-dış düzenleme" arasında anlamlı ilişki tespit edilememiştir.

Sürekli kaygı ile "içsel ve dışsal motivasyon", "uyarıma özgü içsel motivasyon”, "bilgi ve gelişime özgü içsel motivasyon" arasında negatif ve zayıf düzeyde anlamlı ilişki tespit edilmiştir. Sürekli kaygı ile "sonraya bırakılmış içsel motivasyon" arasında negatif ve çok zayıf düzeyde anlamlı ilişki tespit edilmiştir. Sürekli kaygı ile "içsel motivasyon-dış düzenleme", "sosyal statü ve özgüvene dayalı içsel motivasyon" arasında anlamlı ilişki tespit edilememiştir.

\section{Tartışma ve Sonuç}

Yapılan bu araştırmada cinsiyet değişkenine göre uyarıma özgü içsel motivasyon alt boyut puanının istatistiksel olarak anlamlı farklılaştığı görülürken, içsel ve dışsal motivasyon, sonraya bırakılmış içsel motivasyon, içsel motivasyon-dış düzenleme, bilgi ve gelişime özgü içsel motivasyon, sosyal statü ve özgüvene dayalı motivasyon alt boyut puanlarının istatistiksel olarak anlamlı farklılaşmadığı sonucuna ulaşılmıştır. Ramazanoğlu (2018)'e göre etkili bir çalışma şeklinin oluşturulabilmesi için öncelikle personelin motivasyonunun yüksek olması gerekmektedir. Gülşen (2020) 2019-2020 Eğitim-Öğretim döneminde 65’i kadın, 159’u erkek olmak üzere toplam 224 öğretim elemanının Yetenek Yönetimi iş Motivasyonu ve iş Performansı arasındaki ilişkiyi incelemiştir. Araştırmaya katılan öğretim elemanlarının cinsiyet değişkenine göre iş motivasyonu alt boyutlarında herhangi bir farklılık olmadığı sonucuna ulaşılmıştır. Yapılan araştırmalardan elde edilen sonuçlar bu araştırmaya göre incelendiğinde Gülşen (2020) tarafından ulaşılan sonuçlar ile benzerlik göstermemektedir. Uyarıma özgü içsel motivasyon alt boyut puanında erkek çalışanların uyarıma özgü içsel motivasyon puanının kadın çalışanlara oranla daha yüksek olduğu sonucuna ulaşılmıştır. Elde edilen bu sonuca göre, erkek çalışanların iş ile ilgili kendilerini içsel olarak daha iyi bir şekilde motive edebildikleri söylenebilir.

Gençlik ve Spor İI Müdürlüklerine yapılan bu araştırmada içsel motivasyon-dış düzenleme alt boyut puanında, 4 yıl ve altı mesleki kıdeme sahip çalışanlar ile 5-7 yıl mesleki kıdeme sahip çalışanlar arasında farklılıklar olduğu sonucuna ulaşılmıştır. 

195.

Ateş, Yıldız ve Yıldız (2012) İstanbul Adalar ve Güngören ilçelerinde ilköğretim okullarında görev yapan 97 öğretmenin iş motivasyonu düzeylerini incelemişlerdir. Ateş ve diğerleri tarafından yapılan bu araştırmada sonuç olarak, mesleki deneyim değişkeni 10 yıldan fazla olan öğretmenlerin, mesleki deneyim süreleri 10 yıldan az olan öğretmenlere oranla, iş motivasyonu düzeylerinin yüksek olduğu sonucuna ulaşılmıştır. Ateş ve diğerleri (2012) tarafından elde edilen sonuçlar yapılan bu araştırma açısından incelendiğinde benzerlik göstermektedir. Elde edilen bu veriler ışığında, 5-7 yıl arası mesleki kıdeme sahip olan Gençlik ve Spor III Müdürlüğü çalışanlarının merak, duyusu veya öğrenme ihtiyacı, işinde yeterli olabilme isteği ve bu işte başarılı olma arzusunun yüksek düzeyde olduğu söylenebilir.

Gençlik ve Spor İI Müdürlüğü çalışanlarının içsel ve dışsal motivasyon, sonraya bırakılmış içsel motivasyon, içsel motivasyon-dış düzenleme, bilgi ve gelişime özgü içsel motivasyon, sosyal statü ve özgüvene dayalı motivasyon alt boyut puanlarının istatistiksel olarak anlamlı farklılaşmadığı sonucuna ulaşılmıştır. Kara (2015) Eskişehir il merkezide bulunan 575 otel çalışanın örgütsel bağılık ve çalışma motivasyonu düzeylerini incelediği araştırmada otel çalışanlarının içsel motivasyon, dışsal motivasyon, genel motivasyon puanları ortalamalarının cinsiyet değişkenine göre farkılıaşmadığı sonucuna ulaşılmıştır. Yapılan bu araştırmada uyarıma özgü içsel motivasyon alt boyut puanında erkek çalışanların uyarıma özgü içsel motivasyon puanı (23.40), kadın çalışanlardan (22.60) anlamlı şekilde yüksek olduğu sonucuna ulaşımıştır. Kara (2015) tarafından elde edilen bulgular yapılan bu araştırmada elde edilen sonuçlara göre benzerlik göstermektedir.

Gençlik ve Spor II Müdürlüklerine yapılan bu araştırmada 35 yaş ve altı çalışanların içsel ve dışsal motivasyon, uyarıma özgü içsel motivasyon, sonraya bırakılmış içsel motivasyon, içsel motivasyon-dış düzenleme, bilgi ve gelişime özgü içsel motivasyon puanları diğer yaş gruplarından yüksek olduğu görülmektedir. Sosyal statü ve özgüvene dayalı içsel motivasyon puanı ise 36-45 yaş çalışanlarda daha yüksek olduğu sonucuna ulaşılmıştır. 2017- 2018 eğitim ve öğretim yılında Denizli ilinde bulunan 4621 öğretmen ve okul yöneticisinin iş motivasyonu düzeyleri ile örgütsel yabancılaşma düzeyleri arasındaki ilişkiyi inceleyen Gök (2020), tarafından, öğretmenlerin iş motivasyonu ölçeğine vermiş oldukları cevapların cinsiyet, yaş, çalışma süresi ve öğretim düzeylerine göre herhangi bir farklıık bulunmadığı sonucuna ulaşımıştır. Gök (2020) tarafından ulaşılan sonuçlar ile 

195.

yapılan bu araştırmada elde edilen bulgular benzerlik göstermemektedir.

Yapılan bu araştırmada İzmir ilinde çalışanların durumluk kaygı ve sürekli kaygı düzeylerinin Aydın ve Manisa ilinde çalışanlardan yüksek olduğu sonucuna ulaşıImışıı. Uluç ve Duman (2020) Aydın ili Gençlik ve Spor II Müdürlüğünde çalışan bireylerin kaygı durumlarını yarı yapılandııımıs görüşme formu yaklaşımı kullanarak incelemişlerdir. Toplam 25 gönüllü katılımcıya ulaşılan bu araşıırmada Pandemi sürecinin bulaş riski doğurması ve sosyal hayatı olumsuz yönde etkilemesi nedeniyle çalışanlarda kaygı düzeyinin yükselmesine neden olduğu sonucuna ulaşılmıştır. Pamuk, Hamurcu ve Armağan (2014) 234 Öğretmen adayının durumluk ve sürekli kaygı düzeylerini incelmişlerdir. Pamuk ve diğerleri tarafından yapılan araştırmada kadın öğretmen adaylarının sürekli kaygı düzeyleri, erkek öğretmen adaylara göre incelendiğinde anlamlı düzeyde farklııklar olduğu sonucuna ulaşılmıştır. Elde edilen sonuçlar değerlendirildiğinde Uluç ve Duman (2020) ile Pamuk ve diğerleri (2014) tarafından ulaşılan sonuçlar ile benzerlik göstermektedir.

Günal (2020) Mersin Gençlik ve Spor İı Müdürlüğü çalışanlarının DurumlukSürekli kaygı düzeyleri ile Örgüt İklimi arasındaki ilişkiyi incelemiştir. Yapılan araştırmada Mersin Gençlik ve Spor Müdürlüğü çalışanlarının durumluk ve sürekli kaygı puanlarında cinsiyete göre incelendiğinde anlamlı bir farklılık olmadığı sonucuna ulaşılmıştır. Yapılan bu araştırmada kadın çalışanların durumluk kaygı ve sürekli kaygı düzeylerinin erkek çalışanlardan yüksek olduğu sonucuna ulaşılmıştır. Günal (2020) tarafından elde edilen araştırma sonuçları yapılan bu araştırma açısından incelendiğinde; Günal (2020) tarafından elde edilen sonuçlar ile benzerlik göstermemektedir.

Yapılan bu araştırmada durumluk kaygı düzeyinde, lise mezunu çalışanlar ile lisans mezunu çalışanlar arasında farklılık olduğu sonucuna ulaşılmıştır. Fakat Develi (2006) Konya İ merkezinde bulunan Ortaokullarda çalışan Beden Eğitimi Öğretmenleri üzerinde Sürekli Kaygı Ölçeğini uygulamış, Yüksek Lisans ve Lisans diplomalı olanlar arasında bir farklılık olmadığı sonucuna ulaşmışır. Develi (2006) tarafından ulaşılan sonuçlar yapılan bu araştırmada elde edilen bulgulara göre değerlendirildiğinde sonuçlar benzerlik göstermemektedir. Bu araştırmada lisans mezunu çalışanların durumluk kaygı düzeyleri (34.53), lise mezunu çalışanlardan (31.19) anlamlı şekilde yüksek olduğu sonucuna ulaşılışstır. Elde edilen bu sonuca göre, lisans mezunu çalışanların anlık olarak meydana gelen duygu durumlarına göre 

195.

kaygı düzeylerinin yüksek olduğu söylenebilir.

Covid-19 Pandemi sürecinde Manisa, İzmir ve Aydın Gençlik ve Spor II Müdürlüklerinde çalışan bireylerin İş motivasyonu ve kaygı düzeylerinin incelenmesi amacıyla yapılan bu araştırmada elde edilen veriler ışı̆̆ında; Durumluk kaygı ile "içsel motivasyon-dış düzenleme" arasında anlamlı ilişki tespit edilememiştir. Durumluk kaygı iş motivasyonunun diğer alt boyutları arasında negatif ve zayıf düzeyde anlamlı ilişki tespit edilmiştir. Sürekli kaygı ile "içsel motivasyon-dış düzenleme", "sosyal statü ve özgüvene dayalı içsel motivasyon" arasında anlamlı ilişsi tespit edilememiştir. Sürekli kaygı ve iş motivasyonunun diğer alt boyutları arasında negatif ve zayıf düzeyde anlamlı ilişki tespit edilmiştir. Aydın ili Gençlik ve Spor İı Müdürlüğü çalışanlarının iş motivasyonu düzeylerinin Manisa ve İzmir ilinde bulunan Gençlik ve Spor İ Müdürlüğüne oranla daha yüksek olduğu sonucuna ulaşılmıştır.

\section{Öneriler}

1. Manisa, İzmir ve Aydın Gençlik ve Spor İl Müdürlükleri çalışanlarının kurum tarafından motivasyon düzeylerinin arttırılmasına yönelik çalışmaların yapılması önerilmektedir.

2. Manisa, İzmir ve Aydın Gençlik ve Spor II Müdürlüklerinde iş yeri çalışanlarının motivasyonlarının artırılabilmesi ve buna bağlı olarak da iş verimliliğinin artırılabilmesi için var olan çalışma koşullarının iyileştirilmesi önerilmektedir.

3. Manisa, İzmir ve Aydın Gençlik ve Spor II Müdürlüklerine uygulanan durumluk ve sürekli kaygı ölçeğinin diğer bölgelerde bulunan Gençlik ve Spor İI Müdürlüklerine uygulanması önerilmektedir.

4. Gençlik ve Spor III Müdürlükleri çalışanlarının iş motivasyonu düzeylerinin iş verimliliği ve örgütsel bağlılık düzelerine etki edeceği düşünülmektedir. Bu amaçla Manisa, İzmir ve Aydın Gençlik ve Spor İı Müdürlükleri çalışanlarının örgütsel bağlııı düzeylerinin incelenmesi önerilmektedir.

\section{Kaynaklar}

Akarçeşme, C. (2004). Voleybolda Müsabaka Öncesi Durumluk Kaygı ile Performans

Ölçütleri Arasındaki illişki. Yayımlanmamış Yüksek Lisans Tezi, Gazi Üniversitesi, Sağlık Bilimleri Enstitüsü, Ankara 
Alisinanoğlu, F. ve Ulutaş, G. (2000). Çocuklarda Kaygı ve Bunu Etkileyen Etmenler. Milli Eğitim Dergisi, 145, 15-19.

Ateş, H., Yıldız, B. ve Yıldız, H. (2012). Herzberg'in Çift Faktör Kuramı Kamu Okullarında Çalışan Öğretmenlerin Motivasyon Algılarını Açıklayabilir Mi? Ampirik bir araştırma. Bilgi Ekonomisi ve Yönetimi Dergisi, 2(7), 147-162.

Cerit, E., Gümüşdağ, H., Evli, F., Şahin, S. ve Bastik, C. (2013). Elit Kadın Basketbol Oyuncularının Yarışma Öncesi Kaygı Düzeyleri ile Performansları Arasındaki İlişki. Sport Sciences, 8(1), 26-34.

Ciucurel, M. M (2012). Spor Müsabakaları Öncesi ve Sonrası Kaygı, Tepki Süresi ve Performans Arasındaki İlişki. Prosedür-Sosyal ve Davranış Bilimleri, 33 (Aralık), 885-889.

Dalkıran, M. (2018). Değişim Yönetimi Bakımından Incelenen 4+4+4 Eğitim Sisteminin Öğretmenlerin Iş Motivasyonu ile Ilişsisi (Balıkesir Illi Örneği). Yayımlanmamış Yüksek Lisans Tezi. Balıkesir Üniversitesi, Sosyal Bilimler Enstitüsü, Balıkesir.

Develi, E. (2006). Konya'da Ilköğretim Okullarında Görev Yapan Beden Eğitimi Öğretmenlerinin Sürekli Kaygı Durumlarının Incelenmesi. Yayımlanmamış Yüksek Lisans Tezi. Selçuk Üniversitesi, Konya.

Erözkan, İ. (2020). Müzik Öğretmeni Adaylarının Müzik Performans Kaygısı ile Bireysel Çalgı Performans Sınavı Kaygısı Arasındaki Ilişkinin İncelenmesi. Yayımlanmamış Yüksek Lisans Tezi, Muğla Sıtkı Koçman Üniversitesi Eğitim Bilimleri Enstitüsü, Güzel Sanatlar Eğitimi Anabilim Dalı Müzik Eğitimi Bilim Dalı, Muğla.

Ersarı, G. ve Naktiyok, A. (2012). İş Görenin İçsel ve Dışsal Motivasyonunda Stresle Mücadele Tekniklerinin Rolü. Atatürk Üniversitesi Sosyal Bilimler Enstitüsü Dergisi, 16(1), ss.81-101.

Ertürk, R. (2016). Öğretmenlerin İş Motivasyonları. Eğitim Kuram ve Uygulama Araştırma Dergisi, 2(3), ss.01-15.

Ertürk, R. ve Aydın, B. (2017). Öğretmenlerin İş Motivasyonunu Artıran ve Olumsuz Etkileyen Durumların İncelenmesi. Akademik Sosyal Araştırmalar Dergisi, 5(58), ss.582-603. 
Gök, M. (2020). Ortaokullarda Yetenek Yönetiminin Uygulanma Düzeyi ile İş Motivasyonu ve Örgütsel Yabancılaşma Düzeylerinin Incelenmesi. Yayımlanmamış Doktora Tezi, Kırgızistan-Türkiye Manas Üniversitesi Sosyal Bilimler Enstitüsü Eğitim Bilimleri Anabilim Dalı, Bişkek.

Gülşen, B. Y. C. (2020). Akademisyenlerde Yetenek Yönetimi Iş Motivasyonu ve Işs Performansı Illişkisinin İncelenmesi. Yayımlanmamış Yüksek Lisans Tezi, Ankara Yıldırım Beyazıt Üniversitesi Sağlık Bilimleri Enstitüsü, Ankara.

Günal, S. (2020). Örgüt İklimi ile Kaygı (Durumluk - Sürekli) Arasındaki Ilişkinin Incelenmesi: Mersin Gençlik ve Spor II müdürlüğü Çalışanları Üzerine Bir Araştırma. Yayımlanmamış Yüksek Lisans Tezi, Mersin Üniversitesi Eğitim Bilimleri Enstitüsü, Mersin.

Harmancı, E. (2008). F Şıkkı Var mı? İzmir

Kara, Z. (2015). Çalışanların Örgütsel Bağlılık Düzeylerinin Çalışma Motivasyonuna Olan Etkisi ve Bir Araştırma. Yayımlanmamış Yüksek Lisans Tezi, Eskişehir Osmangazi Üniversitesi Sosyal Bilimler Enstitüsü, İşletme Anabilim Dalı, Eskişehir.

Karagüven, H. Ü. (1999). Açık Kaygı Ölçeğinin Geçerlik ve Güvenirliği İle İlgili Bir Çalışma. M.Ü. Atatürk Eğitim Fakültesi Eğitim Bilimleri Dergisi, 11, 203-218.

Karaşar, B. ve Öğülmüş, S. (2016). Üniversite Öğrencilerinde Sosyal Onay İhtiyacının Çeşitli Değişkenler Açısından İncelenmesi. Uludağ Üniversitesi Eğitim Fakültesi Dergisi, 29(2), 469-495.

Mazlum, M. M. ve Atalay, M. A. (2017). Sosyal Bilimlerde Araştırma Yönteminin Belirlenmesi. Route Educational and Social Science Journal, 4(4), 1-21.

Noermijati, P. D. (2015). The Effect of Job Stress and Job Motivation on Employees' Performance Through Job Satisfaction (A Study at PT. Jasa Marga (Parsero) Tbk. Surabaya - Gempol Branch), Journal of Economics, Business and Accountancy Vantura, August - November 18(1), 231-240.

Önen, S. M. ve Kanayran, H. G. (2015). Liderlik ve Motivasyon: Kuramsal Bir Değerlendirme. Birey ve Toplum Sosyal Bilimler Dergisi, 5(2), 43-64.

Öner, N. ve Le Compte, A. (1983). Durumluk-Sürekli Kaygı Envanter El Kitabı. İstanbul. Boğaziçi Üniversitesi Yayınları.

Öner, N. ve Le Compte, A. (1998). Süreksiz Durumluk/Sürekli Kaygı Envanteri El Kitabı. İstanbul: Boğaziçi Üniversitesi Yayınevi. 
Özmutaf, N. M. ve Aktekin E. (2016). Optik Mağazalarında Çalışanların İş Motivasyonuna Yönelik Algıları. İstanbul Global Business Research Congress, 2, ss.412-419.

Pamuk, Y., Hamurcu, H. ve Armağan, B. (2014). Sınıf Öğretmeni Adaylarının Durumluk ve Sürekli Kaygı Düzeylerinin İncelenmesi (İzmir-Buca Örneği). Bartın Üniversitesi Eğitim Fakültesi Dergisi, 3(2), 293-316.

Ramazanoğlu, T.M. (2018). Gençlik Hizmetleri Spor II Müdürlüğü Personelinin İ̧̧ Doyum Düzeylerinin Çeşitli Değişkenler Açısından Karşılaştırılması. Yayımlanmamış Yüksek Lisans Tezi, Sakarya Üniversitesi Eğitim Bilimleri Enstitüsü Beden Eğitimi ve Spor Eğitimi Anabilim Dali Beden Eğitimi ve Spor Öğretmenliği Bilim Dalı, Sakarya.

Robbins, S.P. (1993). Organizational Behavior. New Jersey: Englewood Cliffs: Prentice-Hall

Tükel R. ve Alkın T. (2006). Anksiyete Bozuklukları. Ankara: Türkiye Psikiyatri Derneği Yayınları.

Uluç, E.A. ve Duman, S. (2020). Gençlik ve Spor İı Müdürlüğü Çalışanlarının Covid19 Sürecinde Kaygı Durumlarının İncelenmesi. Akdeniz Spor Bilimleri Dergisi, 3(2), 289-302.

Uzunsakal, E. ve Yildiz, D. (2018). Alan Araştirmalarinda Güvenilirlik Testlerinin Karşilaştirilmasi ve Tarimsal Veriler Üzerine Bir Uygulama. Uygulamalı Sosyal Bilimler Dergisi, 2(1), 14-28.

Yılmaz, B. (2012). The validity and reliability study of work motivation scale for Turkish population. 